\title{
NEW SETTLEMENT FROM THE LA TÈNE PERIOD IN SERE $\check{D}^{1}$
}

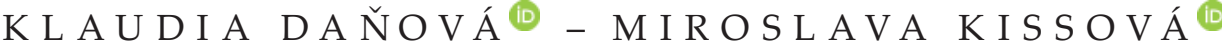

\begin{abstract}
During rescue excavations in the town of Sered, Galanta distr., SW Slovakia, a settlement from the La Tène Period was uncovered. The article analyses two sunken features, pit-houses. A usual set of pottery consisting of bowl and vase shapes, situlas and situla-shaped pots was discovered in their fills. One of the features is well dated by two fragments of bracelets made of sapropelite. Settlement is dated to the Middle La Tène Period.
\end{abstract}

Keywords: Southwestern Slovakia, La Tène Period, pit-house, pottery, bracelets.

\section{INTRODUCTION}

The studied site of Prúdy is located in the northern part of Sered' (Galanta distr., SW Slovakia), near the currently modified stream of the Váh river (Fig. 1). During the rescue excavations in 2018 and 2019 associated with the construction of technical infrastructure for the investment housing construction, a settlement from the Late Iron Age was discovered. The archaeological research consisted of monitoring of excavations during construction of communications in the newly built residential area of Prúdy on both sides of the previously existent road, within length of $980 \mathrm{~m}$ and width of approx. $8 \mathrm{~m}$. The layer of hummus removed from the body of the road was $30 \mathrm{~cm}$ thick. Topsoil was up to $40 \mathrm{~cm}$ thick at some places. Therefore, it was necessary to study the area of the road complexly, by means of purposefully located trenches with depths reaching the sediments with visible features $(50-70 \mathrm{~cm}) .44$ trenches were located in the area of the roads as part of the research. The deeper ditches for pipelines and sewerage were also monitored. Both ditches were led through the body of the road. Nine settlement features were investigated during the excavations (Fig. 1). They were concentrated on a slight elevation - a loess terrace. Besides common settlement pits, two residential features (huts) indicated as no. 5 and 8 were also studied. This study deals with these two features. Finds will be complexly published elsewhere.

Sered' belongs to the towns with relatively good archaeological background. Several sites from various periods of prehistory and the Middle Ages are situated in the urban area of the town and in the immediate vicinity of the archaeological excavations. The important sites, such as Mačianske vŕšky (including settlement from the La Tène Period; Paulík 1955; 1957) and Sered' manor, also include the Area of ZIPP factory. It is located in the immediate vicinity of the studied site of Prúdy. In 1958, a cremation burial from the Late Iron Age was discovered there (Bialeková 1958) and in 1976, skeleton and settlement finds from the Eneolithic and Middle Ages $\left(10^{\text {th }}-11^{\text {th }}\right.$ c.) were added to it (Bialeková 1989, 96; Šalkovský 1976). Excavation at the site of Prúdy, approx. $200 \mathrm{~m}$ south of the detected La Tène features, continued in 2020. The research did not confirm continuation of the La Tène settlement southwards, however, medieval settlement was recorded. ${ }^{2}$

\section{DESCRIPTION OF THE FIND CONTEXT}

Settlement of the La Tène Period was documented on a slight loess elevation, near which extinct meanders of the Váh river were recorded. Features no. 5 and 8 were $36.5 \mathrm{~m}$ far from each other. East of feature no. 5 , in its immediate surroundings, a cluster of daub with pottery was found. It was indicated as feature no. 3. It had irregular shape of $440 \times 320 \times 5 \mathrm{~cm}$. The pottery as well as the daub were discovered just below the topsoil. The same situation was discovered near feature no. 8 . West of it, feature no. 6 was located. It had irregular shape of $206 \times 180 \times 5 \mathrm{~cm}$. The remarkable proximity of features no. 3 and 6 to pit-houses no. 5 and 8 as well as their character suggest that they might have been results of levelling of construction debris from features no. 5 and 8 (Fig. 1).

\footnotetext{
1 The article was supported by grant projects of VEGA no. 2/0001/18 and APVV-18-0276.

2 We thank to B. Kovár for information.
} 


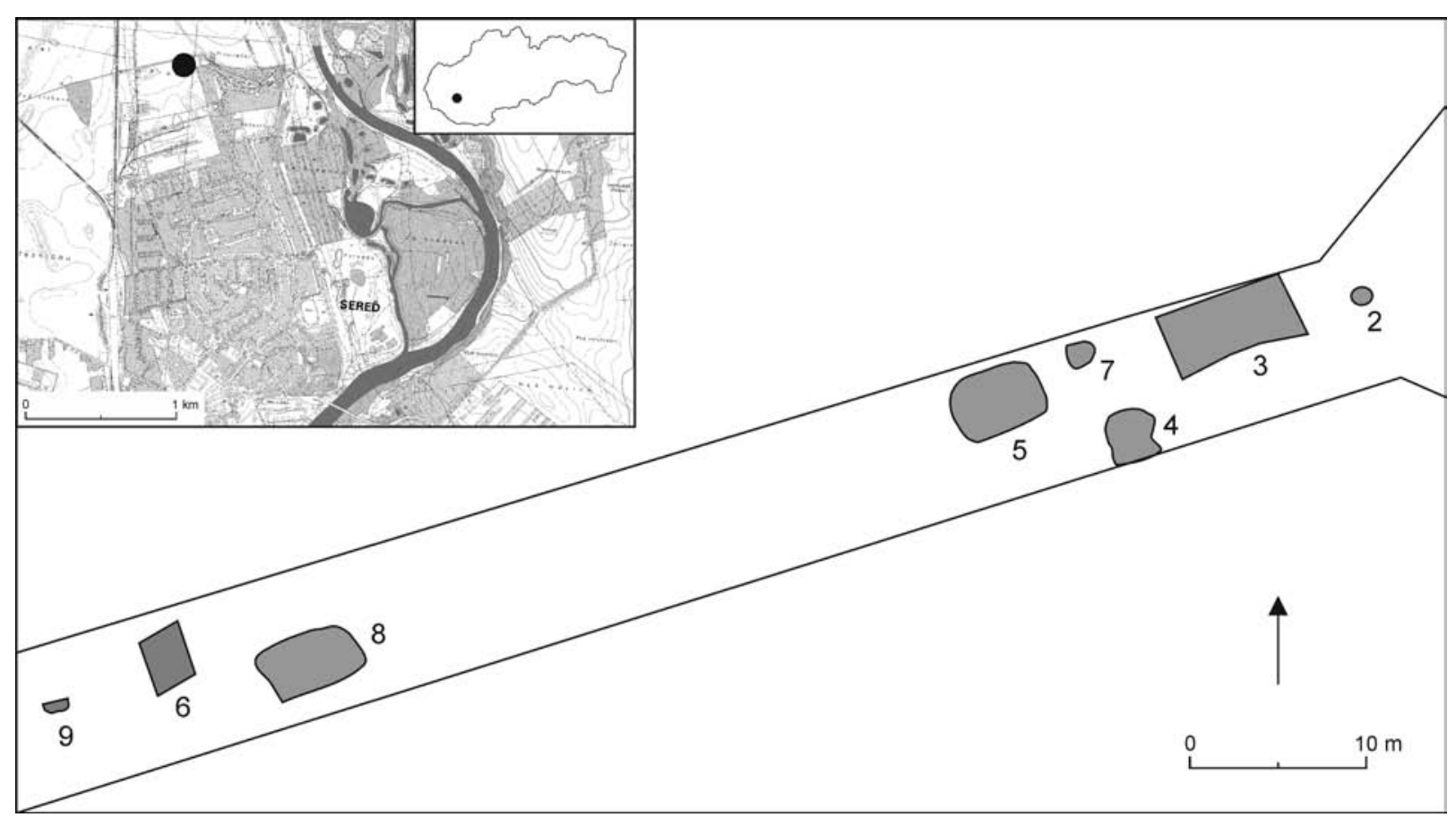

Fig. 1. Sered', Prúdy site. Excavation plan and location of excavated area (author K. Daňová).

Feature no. 5 represents the classical La Tène type of a sunken feature with double pole construction. The pit-house had rectangular shape with slightly rounded corners, walls conically falling to the almost flat bottom and size of $517 \times 350 \times 68 \mathrm{~cm}$ (Fig. 2). It was north-south oriented. The eastern part of the feature was disturbed by trench 26 . The feature had compact fill composed of dark to black loam with numerous sherds (more than $42.8 \mathrm{~kg}$ !), daub, charcoals and animal bones which occurred as early as the level of detection. The fill was homogeneous, without multiple layers. The bottom of the pit-house was sunken in the hard loess layer mixed with small stones, it was almost flat, only disturbed by smaller pits. Two deeper postholes no. 5/2 and 5/7 in the middle of the shorter walls and oriented along the feature's longer axis probably created the basic supporting system of the structure (size of posthole no. $5 / 2: 45 \times 36 \times 72 \mathrm{~cm}$; no. 5/7: $36 \times 34 \times 56 \mathrm{~cm}$ ). Six more holes were identified along the longer walls; they looked like short furrows or double postholes (no. 5/1, 5/5 and 5/8). However, their depth was minimum (posthole no. 5/1: $73 \times 30 \times 20 \mathrm{~cm}$; no 5/3: $52 \times 46 \times 8 \mathrm{~cm}$; no. 5/4: diam. $36 \mathrm{~cm}$, depth $8 \mathrm{~cm}$; no. $5 / 5: 72 \times 42 \times 16 \mathrm{~cm}$; no. 5/6: $42 \times 36 \times 20 \mathrm{~cm}$; no. $5 / 8$ : $72 \times 36 \times 11 \mathrm{~cm}$ ). Their fills were homogenous, dark brown. The function of these pits is disputable. They could have been additional supporting pillars, shallowly sunken, or they might have been sunken by pressure.
Feature no. 8 was identified in the profile of the sewerage furrow and its connection which disturbed the feature from three sides. The preserved shape was rectangular, with rounded corners and walls conically falling to the almost flat bottom and its size was $520 \times 325 \times 58 \mathrm{~cm}$ (Fig. 3). Its fill was almost identical with the sunken terrain and it was composed of dark loam. After the fill had been removed, eight sunken pits were identified in the feature's bottom (with the fill identical with the feature's backfill) and along its central line in the east-west direction, a furrow of $380 \times 68 \times 7 \mathrm{~cm}$ was running. The supporting construction of the feature included double postholes situated along its longer axis, in the middle of the shorter walls; no. $8 / 3$ and $8 / 4$ in the western wall and no. $8 / 5$ and $8 / 6$ in the eastern wall (sizes of postholes: no. 8/3: $37 \times 32 \times 28 \mathrm{~cm}$; no. 8/4: $30 \times 26 \times 46 \mathrm{~cm}$; no. 8/5: $52 \times 42 \times 62 \mathrm{~cm}$; no. 8/6: diam. $32 \mathrm{~cm}$, depth $53 \mathrm{~cm}$ ). Larger holes with circular ground plans and bowl-shaped bottoms were uncovered in the southwestern (hole no. 8/1: diam. $66 \mathrm{~cm}$, depth $30 \mathrm{~cm}$ ) and north-western corners of the pit-house (hole no. 8/2: diam. $70 \mathrm{~cm}$, depth $31 \mathrm{~cm}$ ). Hole no. $8 / 1$ was partly covered by a large flat burned stone. In the eastern part of feature no. 8 , oval holes no. $8 / 7$ and $8 / 8$ were studied (sizes: no. $8 / 7$ : $60 \times 50 \times 40 \mathrm{~cm}$; no. 8/8: $103 \times 75 \times 47 \mathrm{~cm}$ ). Nevertheless, it is not clear from the find context whether this was a superposition of several features or 

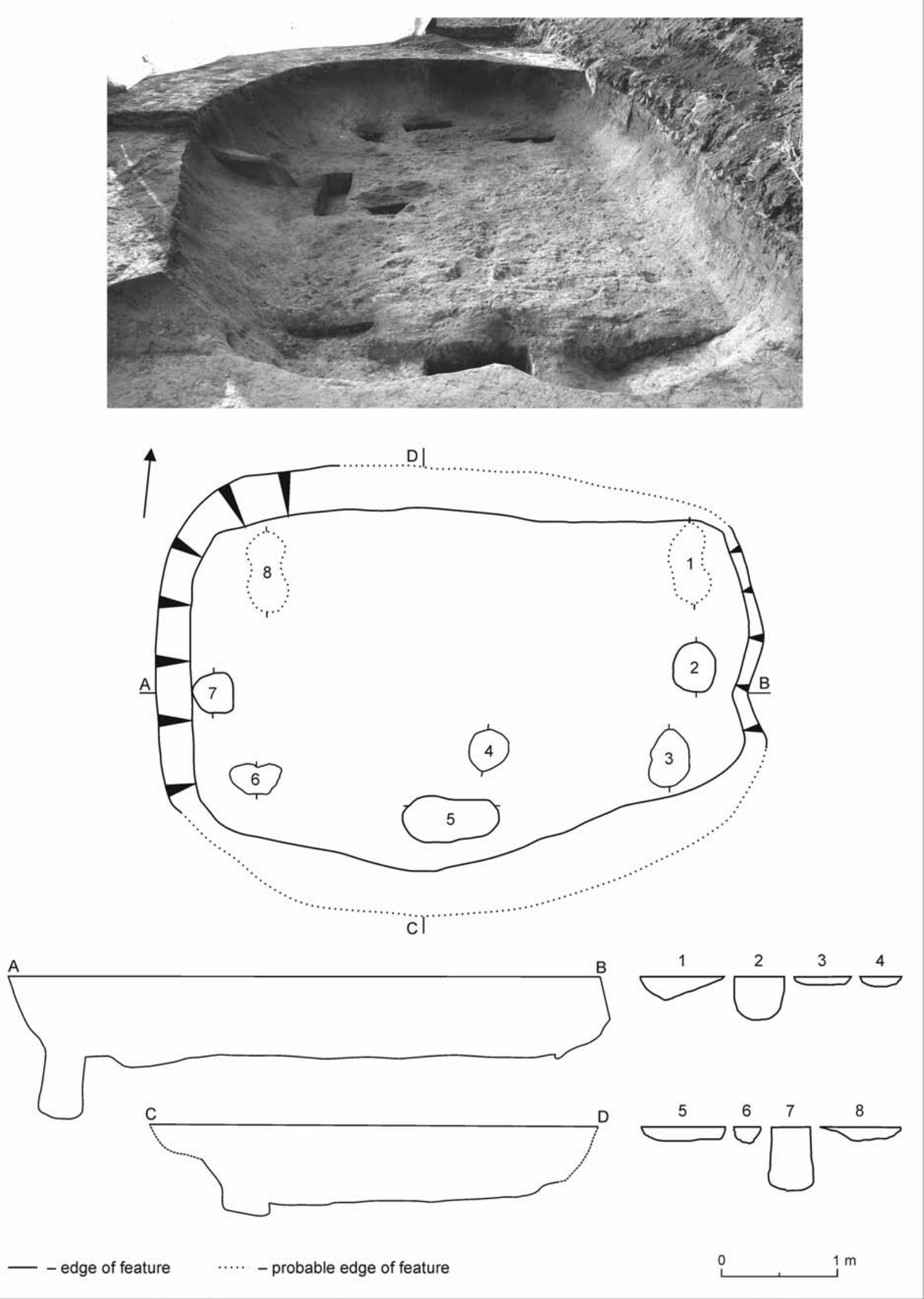

Fig. 2. Sered', Prúdy site. Feature no. 5 (photo and drawn by K. Daňová). 

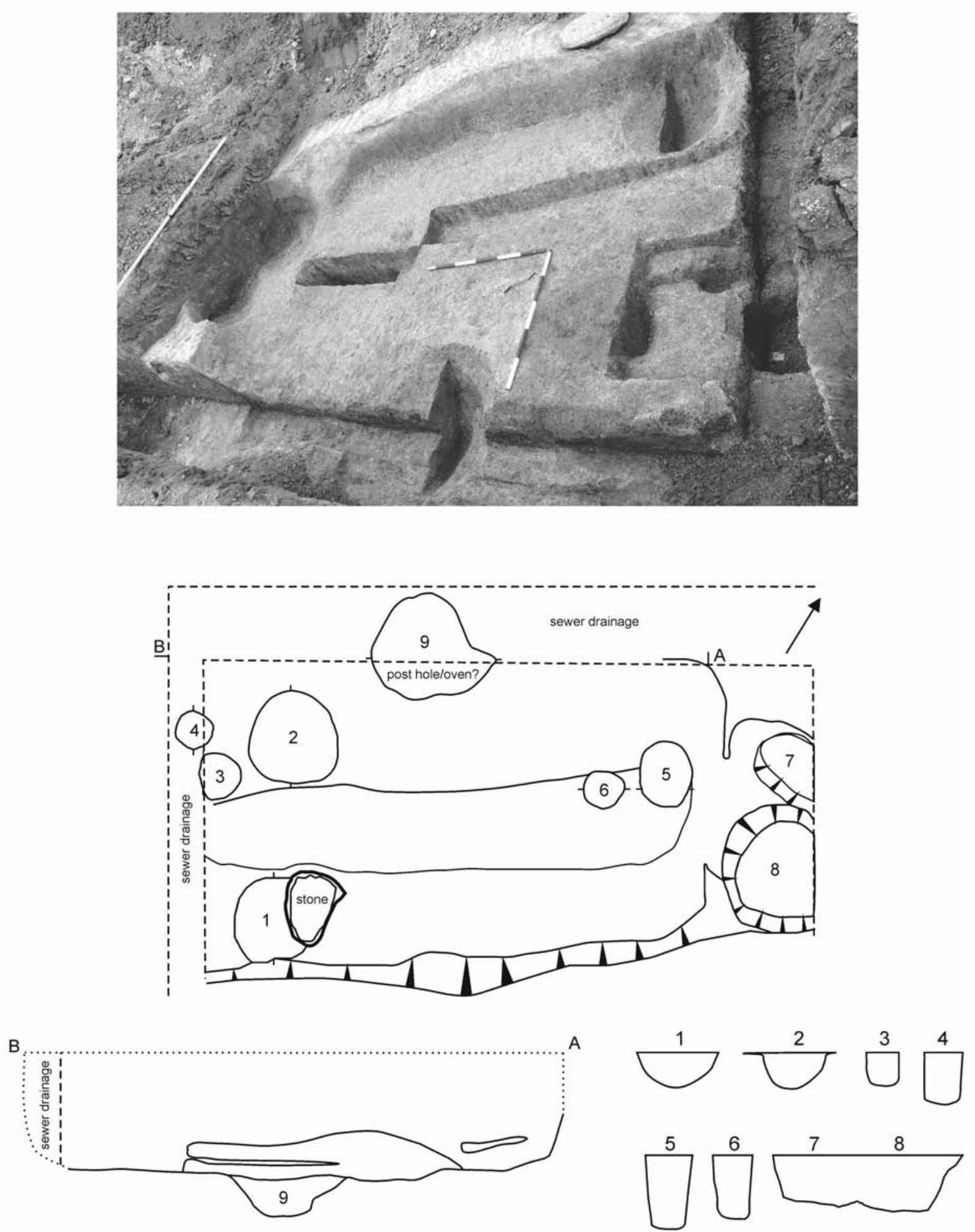

- - edge of feature

- probable edge of feature

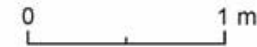

Fig. 3. Sered', Prúdy site. Feature no. 8 (photo and drawn by K. Daňová). 
an entrance recess as part of feature no. 8. Fill of pits no. $8 / 7$ and $8 / 8$ was no different from the fill of feature no. 8 itself. In the northern part of the feature, approximately in the middle, a burned area (hearth?) indicated as feature no. 8/9 of $100 \times 82 \times 52 \mathrm{~cm}$ was located. Its backfill consisted of a burned layer with charcoals.

Both features represent the most commonly occurring type of pit-houses at La Tène settlements of southwestern Slovakia which can be classified into the basic type A according to the classification by J. Meduna (1980, 48-56) with two postholes located on the longer central axis, in the middle of the shorter walls. From the aspect of construction, doubled bearing poles in feature no. 8 are interesting. However, it is not possible to say from the find context whether it was an additional repair supporting the roof or the poles were sunken during the pit-house's construction. The depth to which the poles are sunken is usually evidence of additional building of a roof; the hole left by a secondary pole is normally shallower. Postholes no. $8 / 5$ and $8 / 6$ were approx. equally sunken 62 or $52 \mathrm{~cm}$ deep. On the other hand, postholes near the western wall show greater differences in depth. Posthole no. $8 / 3$ was sunken 'only' $28 \mathrm{~cm}$ deep, while post considerably variable. Additional postholes or other depressions in the floors are not exceptional. At the settlement in Nitra-Šindolka, they were recorded e.g. in features no. $12 / 68,68 / 75$, 176/85 and 190/86 (Březinová 2000, fig. 7; 15; 38; 43; 44). Pits reaching below the floor level were also found at the settlement in Nitra-Chrenová II in feature no. 20/71 as well as at Nitra-Mikov dvor, Construction of electricity substation site, in features no. 74/80 or 293/84 (both sites Březinovál Chropovský 2020, fig. 14; 20; 31). Other holes were studied also in the interiors of pit-houses at the site of Prúdy. Six shallow holes with irregular ground plans and shape of short furrows or doubled postholes were discovered along the inner circumference of feature no. 5. Nevertheless, they were well distinguishable from the feature's floor in the terrain. Here, the question arises whether it was a supporting system of the house or they were just holes made on purpose when the house was used, e.g. depressions for depositing large vessels for storing food, the shallower holes might have been created by pressure of heavy and massive furniture (e.g. for sitting). In feature no. 5, traces of a heating device were not detected, although ashes were identified in the backfill of posthole no. 5/6.

Feature no. 8 had more complex construction elements. In its eastern part, holes no. $8 / 7$ and 8/8 were detected. Their fill was no different from the backfill of the whole feature no. 8. In the place where both holes ended, the feature's walls widened northwards and southwards. The find context suggests that an entrance recess in the feature was located there. Entrances to the pit-houses were identified also at the settlement in Nitra-Šindolka in pit-house no. 12/68 and 189/86 (Březinová 2000, fig. 7; 43), at the settlement in Komjatice, Kňazova jama site, in feature no. 173/79 (Horváth 2014, 72, 73) or in feature no. 69 studied at the site of Pri mlyne in Čierne Klačany (Březinová et al. 2015, 265). Another element in feature no. 8 was a shallow furrow running through the centre of the feature. Its function, similarly to the function of two large holes in the western part of the feature, is unknown. Holes no. $8 / 1$ and $8 / 4$ were 'twins' with their shapes and sizes; they were located on both sides of the furrow. The holes might have had a working function. The eastern part of hole no. 8/1 was covered with a large stone, which was considerably weathered or burned - it was friable. It is not probable that it was part of the pole's supporting structure. As it was a flat stone, it might have been part or base of a heating device, which might be documented by the fact that it was significantly burned. Approximately in the middle of the northern wall of feature no. 8 , hole no. $8 / 9$ was located. It was burned and charcoals were discovered in its fill. With its shape and size, it resembled holes no. 8/1 and 8/2, but with regard to its size, it could have been a heating device - sunken hearth. Traces of fire are not rare nor common finds in La Tène pit-houses. At the settlement in Nitra-Šindolka, remains of fire were found in two out of 32 pit-houses (features no. 72/75 and 128/76: Březinová 2006a, 16); in Komjatice, a stove was documented in feature no. VI/79 (Horváth 2014, 71), in Nitra-Šindolka, Športový areál site, a hearth was found in feature no. 8/83 (Chropovský/Fusek 1988, 144, 145). As many as five hearths were found in feature no. 1 at the site of Cífer, Záhumenice site. According to the authors of the excavation, it was probably a production feature where hearths were gradually built in various parts of the pit-house (Cheben/Ruttkay/Ruttkayová 2012, 295, fig. 1: 6). Traces of small pointed holes in the floor or remains of benches were not detected in any of the features at the site of Prúdy. The interior area of the pit-houses is $18.10 \mathrm{~m}^{2}$ for feature no. 5 and at least $16.9 \mathrm{~m}^{2}$ for feature no. 8. Compared to the average size of pit-houses, which is $14.37 \mathrm{~m}^{2}$ in the territory of southwestern Slovakia (Březinová $2006 a, 18)$, the features from the site of Prúdy rank among the larger ones. 


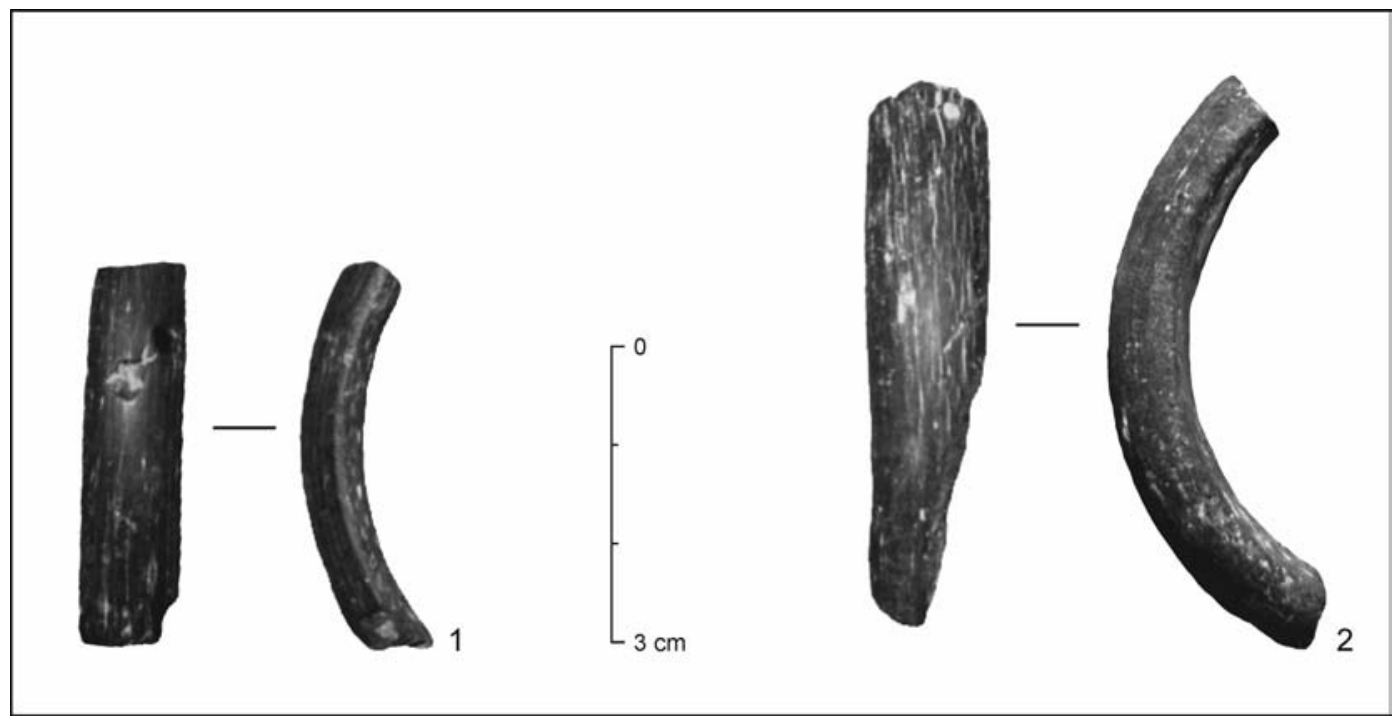

Fig. 4. Sered', Prúdy site. Fragments of sapropelite bracelets from feature no. 5 (photo by M. Kissová).

\section{EVALUATION OF FINDS}

The considerable part of the assemblage of finds obtained from both studied features consists of fragments of vessels; in feature no. 5 their weight is more than $42.8 \mathrm{~kg}$. Apart from pottery, two fragments of sapropelite bracelets, one spindle whorl, several clay discs, whetstones, fragments of clay weights, two unidentifiable iron fragments, daub and animal bones were discovered. Similarly, to production waste, iron slag occurred in the backfill of feature no. 5. Feature no. 8's backfill was poorer in finds. Together with pottery fragments, a bone awl, a grinding slab and animal bones were found in it. Chronologically sensitive artefacts, mainly brooches, are absent among the finds. Only the fragments of sapropelite bracelets and pottery can date the features more exactly.

Two fragments of sapropelite bracelets stand out among the above-mentioned finds (Fig. 4; Pl. III: 12, 13). Both exemplars had cross-section in shape of rounded letter $D$, which classifies them into type $C$ according to the classification by J. Bujna (2005, fig. 21). The fragment of a sapropelite bracelet published by J. Paulík $(1957,802)$ also comes from Sered. Sapropelite jewels are rather exceptional finds at settlements from the La Tène Period. G. Březinová $(2018,35)$ has recorded 31 sites with finds of sapropelite rings from the territory of Slovakia. Their occurrence at burial grounds is associated mainly with LTB2-LTC1 horizon (Bujna 2005, 19).

A large number of pottery material containing fragments of typical Middle La Tène pottery made on potter's wheel as well as without it comes from feature no. 5. Identical character can be observed on finds from feature no. 8, which includes only fragmentary sherds. The share of hand-made pottery in the processed assemblage is rather low. The most frequent vessel shapes included bowls and bowl-shaped vessels. The wheel-made pottery contained mainly bowls with S-shaped profiles (Pl. II: 1, 5, 6, 9-11, 15, 16; III: 2, 9, 10; V: 7, 8, 10, 12). In most cases, the profile of the belly was slightly rounded; slightly sharp bellies are less frequent (Pl. II: 9; III: 2, 9, 10). The second group of bowls occurring in the backfill of features no. 5 and 8 contained exemplars with inverted mouths, also with slightly rounded profiles (Pl. II: 4, 7, 8, 13, 17; III: 1, 3, 7). The bowls' surface was decorated only with shallow engraved peripheral lines. Stamped or polished decoration occurring at the end of LTC1, but typical mainly of stage LTC2 (Březinová 1996, 155; 2006b, 313), was not identified on any exemplar. Exemplars of conical or biconical handmade bowls were represented by minimum numbers (Pl. I: 2). Compared to bowls and bowl shapes, other types of vessels were much less frequent in the assemblage. As for situlas and situla-shaped pots, the type with slightly inverted mouths and thickened rims of various profiles was predominant (Pl. I: 4, 8-15; III: 6; IV: 1, 3-6; V: 6, 9), including bodies and bottoms (Pl. I: 6; IV: 7, 8, 10, 11; V: 1, $3-5)$. In one case, a plastic horizontal band below the neck decorated with engraved decoration was identified (Pl. I: 15). Bodies of these vessels were usually decorated by means of vertical combing, 
undecorated exemplars are rare (Pl. I: 4, 15; III: 6). Oblique or metope-shaped combing has not been recorded. Situlas with addition of graphite as well as without it were found. Some of them, mainly the graphite exemplars, had reparation holes below their necks (Pl. I: 11; III: 6; IV: 4, 5; V: 9). On the bottom of one situla, in its middle, a mark in shape of a circular shallow groove was documented (Pl. V: 1). However, the fragmentariness of sherd does not enable to attribute it to the certain type. Based on the typological classification of marks, it can be classified in the case of empty wheel into Kappel 5 subtype (Kappel 1969, fig. 52). Marks on vessel bottoms are basically associated only with graphite situlas. It is assumed that they are marks of individual production centres or workshops with production of this vessel type (Hlava 2008, 216). The assemblage probably contained also hand-made pots with inverted mouths and nonprofiled flat or rounded rims whose surface was undecorated or decorated plastically in form of pressed peripheral tapes (Pl. I: 5). Several exemplars represented vases (Pl. III: 4, 5, 8, 11; IV: 12) and bottles (Pl. I: 7). Part of a vase-shaped vessel with decoration on the interface of the body and neck in form of a wave line from feature no. 5 (Pl. III: 11) belongs to the best-preserved exemplars. The inventory from features no. 5 and 8 will be published in detail elsewhere, together with other assemblages of finds from the site of Prúdy.

\section{CONCLUSION}

During the archaeological excavations in Sered, Prúdy site, nine settlement features were studied. Residential features indicated as feature no. 5 and 8 are most remarkable among them. Both pit-houses represent typical Celtic construction of sunken features with two postholes in the middle of their shorter walls which occurred at most La Tène settlements in southwestern Slovakia (Březinová 2000; 2006a; Březinová/Chropovský 2020; Kuzmová 1980, 318). The settlement features can be considered contemporary, belonging to the horizon of the Middle La Tène Period. This is suggested by the fragments of vessels which can be classified into basic pottery shapes of the La Tène Period. More than $42 \mathrm{~kg}$ of sherd fragments come from the fill of feature no. 5; the inventory was preserved in fragments and it was not possible to reconstruct a single complete vessel. The number of sherds and fragmentary miniature artefacts suggest that feature no. 5 was after its primary, probably residential, function had ended - secondarily used as a refuse pit for damaged or useless objects and pottery. The preliminary analysis of the pottery inventory from both features allows their chronological classification into stage LTB2-LTC1, eventually at the beginning of stage LTC2. It is suggested by the absence of younger elements on pottery, including polished decoration on bowls and oblique or metope-shaped combing on situlas. Also, the remarkable prevalence of finer round profiles of bowls and bowl-shaped vessels in the pottery assemblage supports this dating, since there is an assumption of their development from finely rounded profiles to sharper profiles; the peak of this tendency is represented by bowls of Békasmegyer type (Čambal 2011, 105). Dating to the Middle La Tène Period is confirmed by the finds of fragments from bracelets made of sapropelite. This jewel is very popular mainly in stage LTB2 and in the beginning of the following stage LTC1 (Březinová 2018, 40, 41). 

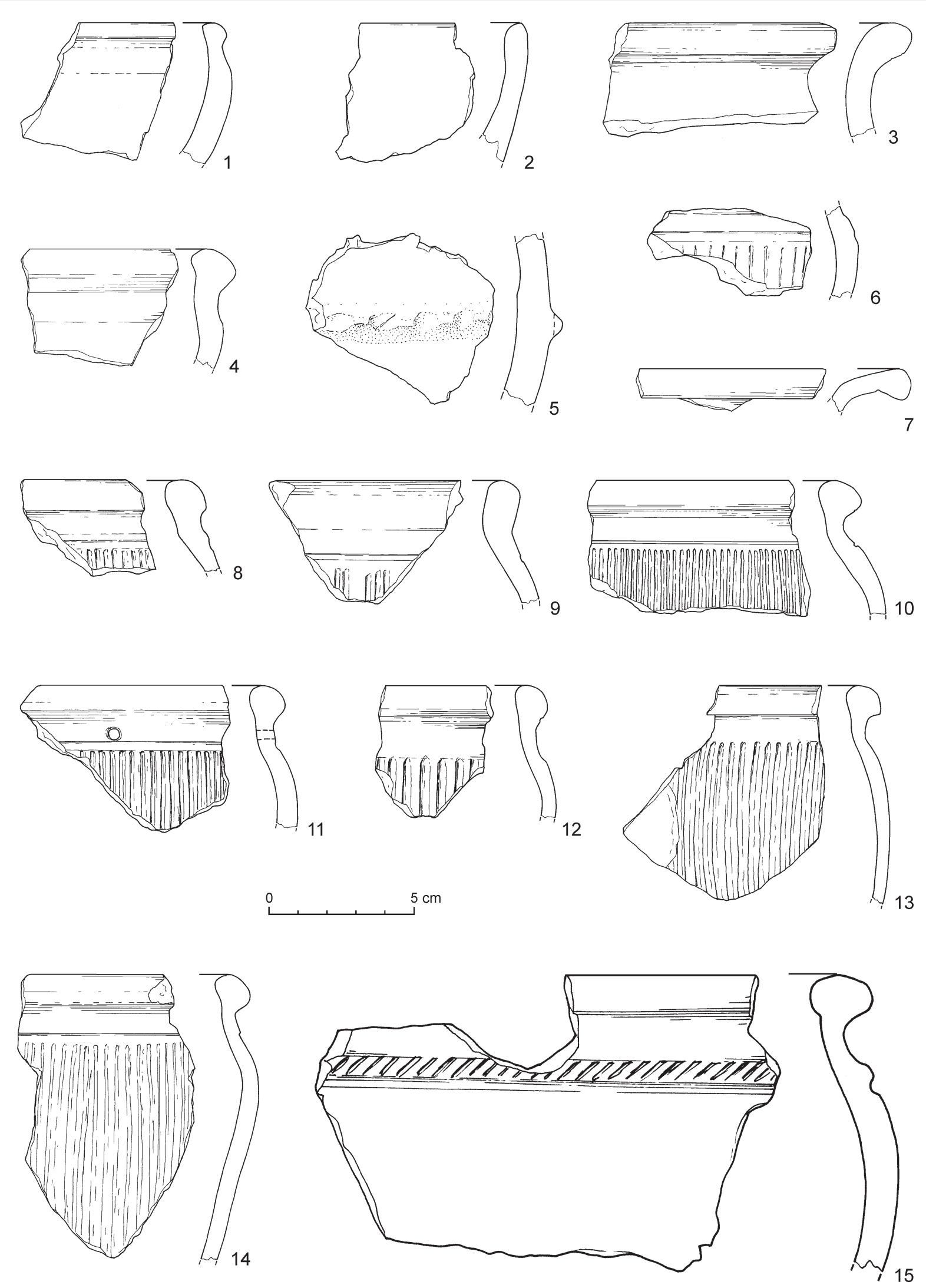

Pl. I. Sered', Prúdy site. Feature no. 5. Selected finds (drawn by Z. Nagyová). 


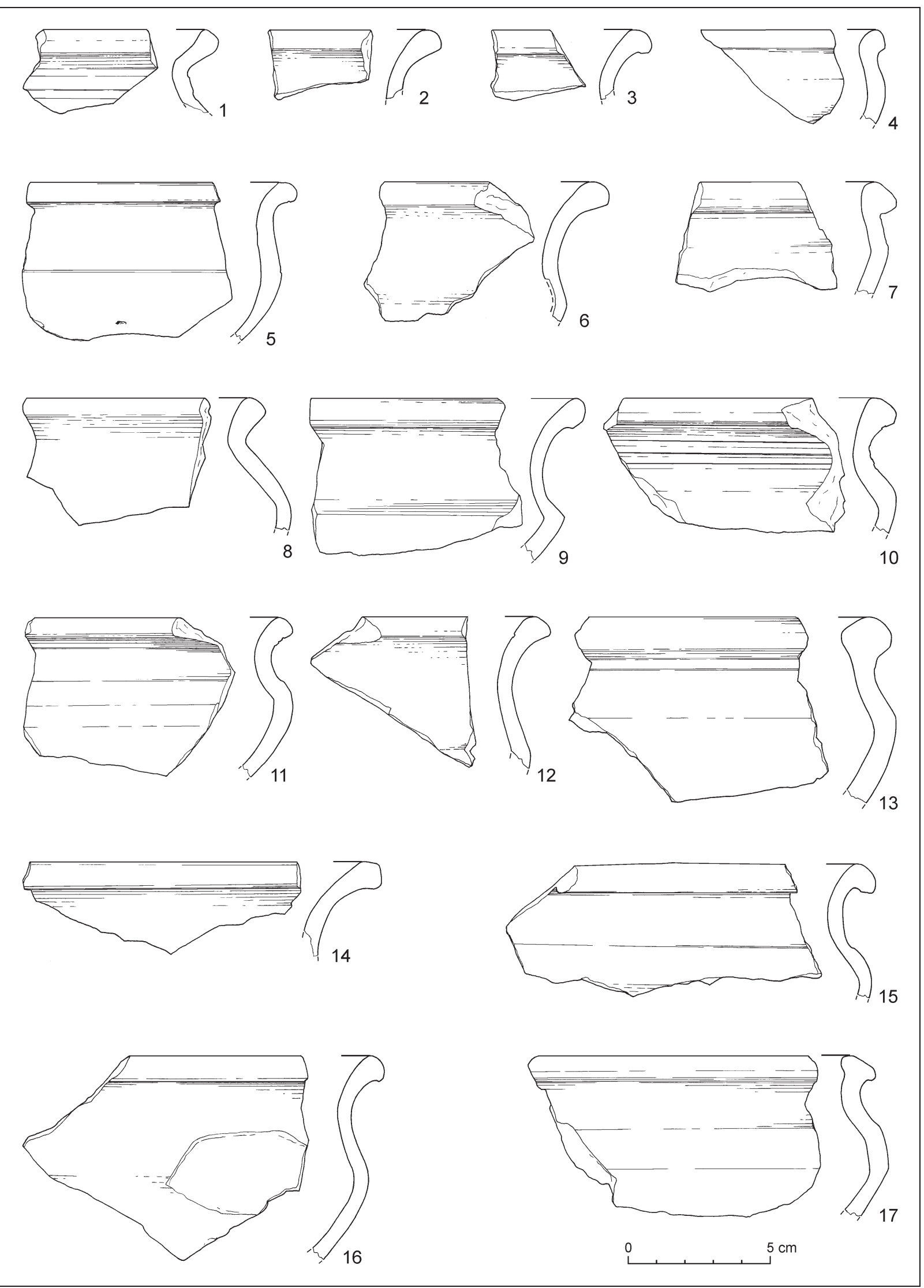

Pl. II. Sered', Prúdy site. Feature no. 5. Selected finds (drawn by Z. Nagyová). 

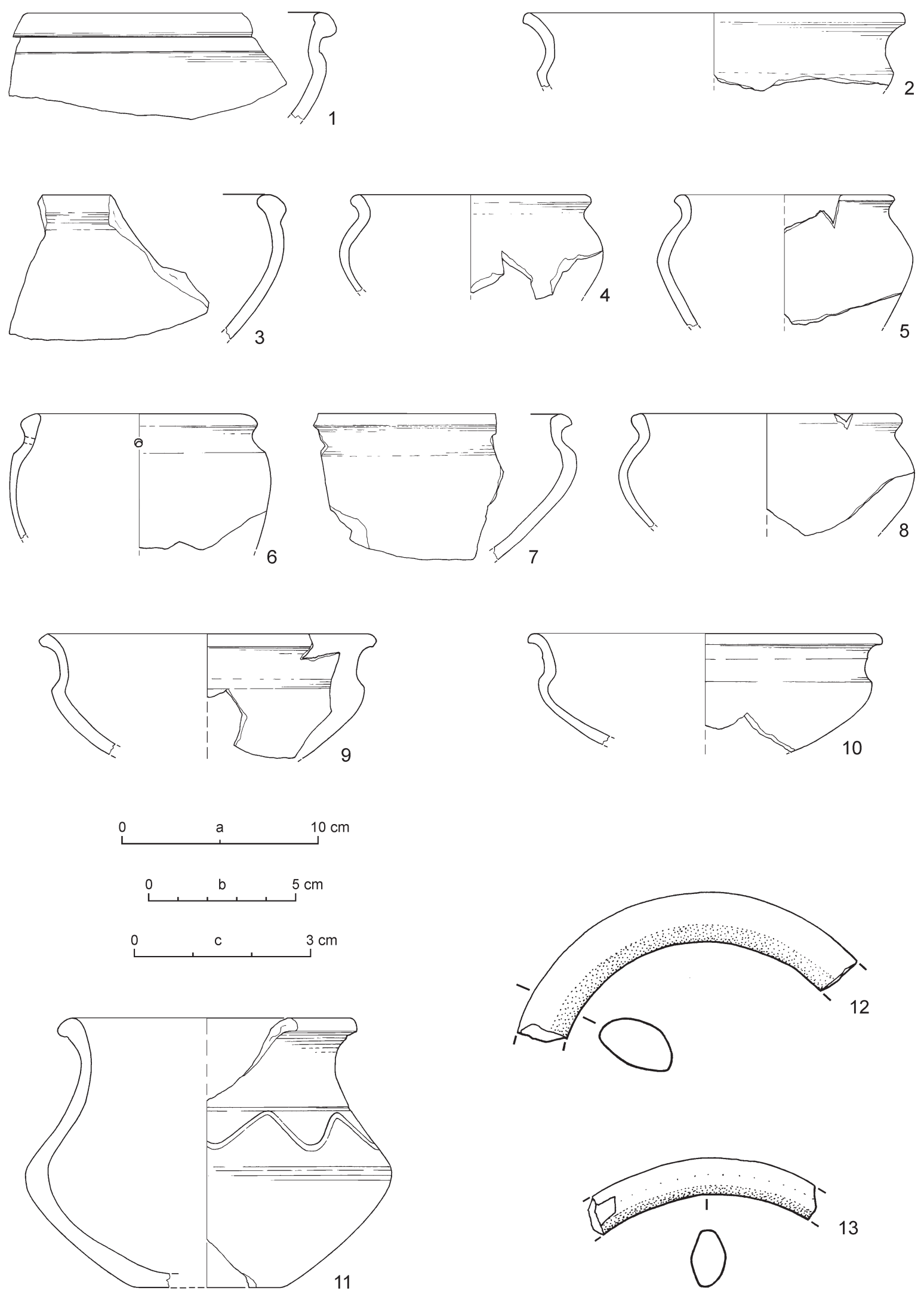

Pl. III. Sered', Prúdy site. Feature no. 5. Selected finds (drawn by Z. Nagyová). Scale: a - 1-10; b-11; c-12, 13. 

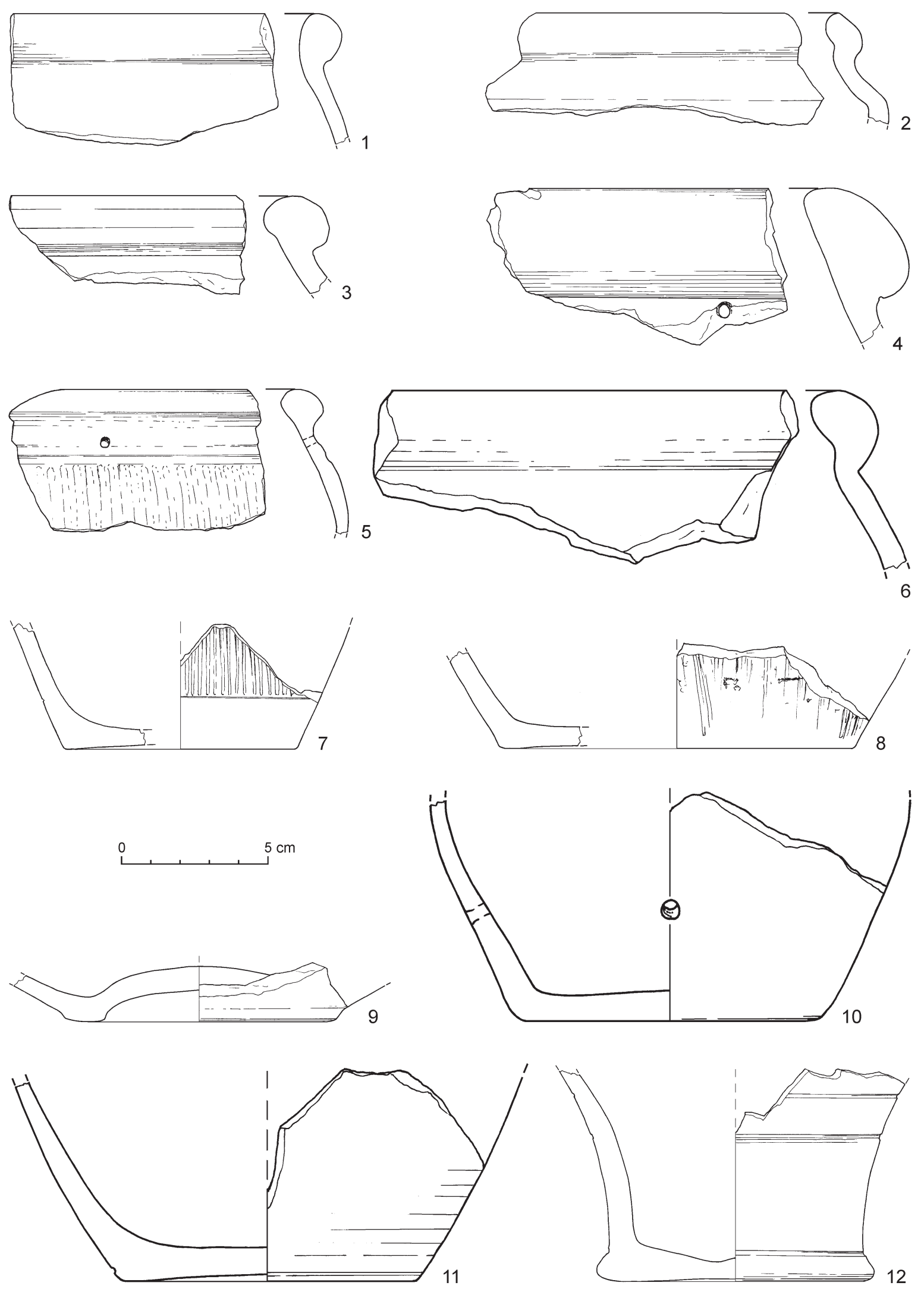

Pl. IV. Sered', Prúdy site. Feature no. 5. Selected finds (drawn by Z. Nagyová). 


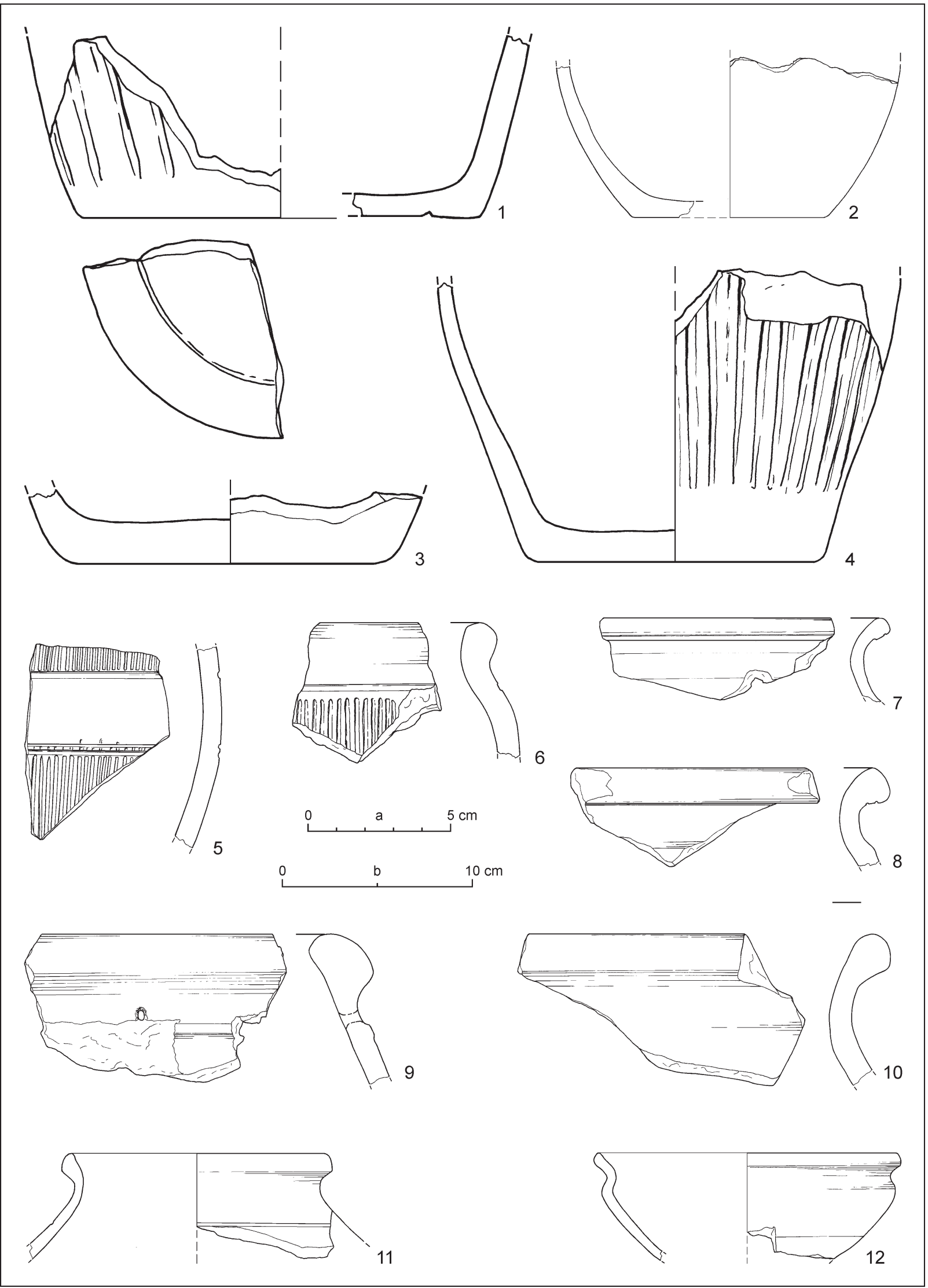

Pl. V. Sered', Prúdy site. 1-4 - feature no. 5; 5-12 - feature no. 8. Selected finds (drawn by Z. Nagyová). Scale: a - 1-10; $\mathrm{b}-11,12$. 


\section{BIBLIOGRAPHY}

Bialeková 1958 - D. Bialeková: Sered’. Nitra 1958. Výskumná správa 422/58. Dokumentácia AÚ SAV Nitra. Unpublished.

Bialeková 1989 - D. Bialeková (zost.): Pramene k dejinám osídlenia Slovenska z konca 5. až 13. storočia. I. zväzok. Bratislava, hlavné mesto SSR a Západoslovenský kraj. Nitra 1989.

Březinová 1996 - G. Březinová: Laténske sídlisko v Šali-Veči v okrese Galanta. Študijné zvesti AÚ SAV 32, 1996, 141-158.

Březinová 2000 - G. Březinová: Nitra-Šindolka. Siedlung aus der Latènezeit. Katalog. Archeologica Slovaca Monographiae. Catalogi 7. Nitra 2000.

Březinová 2006a-G. Březinová: Sídliská a sídliskové nálezy z laténskej doby na juhozápadnom Slovensku. Študijné zvesti Aú SAV 40, 2006, 9-50.

Březinová $2006 b$ - G. Březinová: Laténske sídlisko vo Výčapoch-Opatovciach. Pravěk. Nová řada 16, 2006, 309-324.

Březinová 2018 - G. Březinová: Šperk zo skla a sapropelitu u Keltov na Slovensku. Archaeologica Slovaca Monographiae. Studia 30. Nitra 2018.

Březinová/Chropovský 2020 - G. Březinová/B. Chropovský: Sídliská z doby laténskej v Nitre. Archaeologica Slovaca Monographiae. Fontes 27. Nitra 2020.

Březinová et al. 2015 - G. Březinová/M. Cheben/M. Ruttkay/ M. Vojteček: Dve sídliská z doby laténskej na hornom Požitaví. In: J. Bartík (red.): Zborník na pamiatku Jozefa Paulíka. Štúdie. Zborník SNM. Archeológia. Supplementum 9. Bratislava 2015, 255-274.

Bujna 2005 - J. Bujna: Kruhový šperk z laténskych ženských hrobov na Slovensku. Nitra 2005.

Manuscript accepted 2. 10. 2021

Translated by Viera Tejbusová

PhDr. Klaudia Daňová, PhD.

Archeologický ústav SAV

Akademická 2

SK - 94921 Nitra

klaudia.danova@gmail.com
Čambal 2011 - R. Čambal: Sídliskové objekty zo strednej a neskorej doby laténskej v Slovenskom Grobe. Zborník SNM 105. Archeológia 21, 2011, 83-114.

Cheben/Ruttkay/Ruttkayová 2012 - I. Cheben/M. Ruttkay/ J. Ruttkayová: Zahlibené chaty z doby laténskej v Cíferi. In: G. Březinová/V. Varsik (eds.): Archeológia na prahu histórie. K životnému jubileu Karola Pietu. Archaeologica Slovaca Monographiae. Communicationes 14. Nitra 2012, 289-298.

Chropovský/Fusek 1988 - B. Chropovský/G. Fusek: Výsledky výskumov na stavenisku športového areálu v Nitre. Študijné zvesti AÚ SAV 24, 1988, 143-156.

Hlava 2008 - M. Hlava: Grafit v době laténské na Moravě. Památky archeologické 99, 2008, 189-258.

Horváth 2014 - P. Horváth: Laténske sídlisko v Komjaticiach, poloha Kňazova jama. Študijné zvesti AÚ SAV 56, 2014, 69-110.

Kappel 1969 - I. Kappel: Die Graphittonkeramik von Manching. Die Ausgrabungen in Manching 2. Wiesbaden 1969.

Kuzmová 1980 - K. Kuzmová: Nížinné sídliská z neskorej doby laténskej v strednom Podunajsku. Slovenská archeológia 28, 1980, 313-338.

Meduna 1980 - J. Meduna: Die latènezeitlichen Siedlungen in Mähren. Praha 1980.

Paulík 1955 - J. Paulík: Halštatská a halštatsko-laténska osada pri Seredi. Slovenská archeológia 3, 1955, 135-194.

Paulík 1957 - J. Paulík: Halštatsko-laténske osídlenie Mačanských vŕškov pri Seredi. Archeologické rozhledy 9, 1957, 784, 795, 801-804.

Šalkovský 1976 - P. Šalkovský: Sered'. Nitra 1976. Výskumná správa 3057/76. Dokumentácia AÚ SAV Nitra. Unpublished.

Mgr. Miroslava Kissová, PhD.

Archeologický ústav SAV

Akademická 2

SK - 94921 Nitra

miroslava.svihurova@gmail.com 
